\title{
Pengaruh Kompensasi dan Komunikasi terhadap Motivasi dan Kinerja Pegawai di Kantor Ketahanan Pangan kabupaten Klaten
}

\author{
Dasmadi \\ Program Studi Manajemen, Fakultas Ekonomi, Universitas Boyolali \\ dasmadi@uby.ac.id
}

\begin{abstract}
Abstrak Penelitian ini bertujuan untuk mengetahui pengaruh kompensasi dan komunikasi terhadap motivasi dan kinerja pegawai di Kantor Ketahanan Pangan Kabupaten Klaten. Data yang digunakan adalah data primer dengan mengambil sampel 45 pegawai, Tehnik pengambilan sampel menggunakan metode sensus Alat analisis menggunakan analisis jalur. Hasil Uji t menunjukkan bahwa kompensasi berpengaruh tidak signifikan terhadap motivasi. Komunikasi berpengaruh signifikan terhadap motivasi. Kompensasi berpengaruh signifikan terhadap kinerja pegawai. Komunikasi berpengaruh tidak signifikan terhadap kinerja pegawai. Motivasi berpengaruh signifikan terhadap kinerja pegawai Hasil uji F menunjukkan bahwa secara simultan variabel kompensasi, komunikasi, motivasi berpengaruh positif dan signifikan terhadap kinerja pegawai. Hasil uji koefisien determinasi Total $85,5 \%$. Ini berarti bahwa kinerja pegawai dijelaskan oleh variabel kompensasi, komunikasi, motivasi sebesar $85,5 \%$ dan sisanya sebesar $14,5 \%$ dijelaskan variabel lain diluar model penelitian misalnya lingkungan kerja. Berdasarkan hasil analisis menunjukkan bahwa variabel intervening tidak effektif. Variabel kompensasi secara langsung efektif meningkatkan kinerja pegawai, karena mempunyai pengaruh yang paling besar, positip dan signifikan.
\end{abstract}

Kata Kunci kompensasi, komunikasi, motivasi dan kinerja pegawai.

\section{PENDAHULUAN}

Kantor Ketahanan Pangan Kabupaten Klaten merupakan unsur Lembaga Teknis Daerah yang melaksanakan tugas yang spesifik oleh karena tugas yang dilakukan, sifatnya tidak tercakup oleh Sekretariat Daerah dan Dinas maka untuk mendukung pelaksanaan tugas-tugas yang dilakukan yaitu meliputi melaksanakan urusan pemerintahan di bidang ketahanan pangan, melalui kebijakan teknis dan pembinaan pelaksanaan kegiatan untuk penyangga ketahanan pangan, kelembagaan usaha masyarakat dalam berketahanan pangan dan penyelenggaraan penyuluhan pertanian dalam arti luas serta tugas lain yang diberikan oleh bupati sesuai dengan perundangundangan yang berlaku disamping pelaksanaan dan evaluasi penyelenggaraan sistem ketahanan pangan yang meliputi ketersediaan pangan, distribusi pangan dan penganekaragaman jenis pangan, mendukung kinerja pemerintah daerah menyelenggarakan pemerintahan dan pelaksanaan pembangunan 
Beberapa permasalahan yang menyangkut sumber daya manusia Kantor Ketahanan Pangan Kabupaten Klaten menurut peneliti adalah:

1. Masalah kompensasi. Kompensasi diberikan dengan tujuan memberikan rangsangan dan sarana prasarana kepada pegawai untuk meningkatkan prestasi kerja, serta efisiensi dan efektivitas kerja pegawai. Oleh karena itu, bila kompensasi diberikan secara benar, para pegawaiakan lebih terpuaskan dan tersarana prasarana untuk mencapai sasaran-sasaraninstansi, tetapi jika para pegawai memandang kompensasi tidak memadai, prestasi kerja, sarana prasarana dan kepuasan kerja para pegawai bisa turun secara drastis karena memang kompensasi itu penting bagi pegawai sebagai individu karena besarnya kompensasi mencerminkan ukuran nilai karya pegawai di antara para pegawai itu sendiri.

2. Masalah komunikasi juga berperan dalam peningkatan kinerja pegawai. Pemeliharaan hubungan dengan pegawai memerlukan komunikasi yang efektif. Terlepas dari besar kecilnya suatu organisasi, menyelenggarakan komunikasi secara terus menerus merupakan suatu keharusan. Dikatakan demikian karena melalui komunikasi berbagai hal yang menyangkut kehidupan organisasi disampaikan oleh satu pihak ke pihak yang lain (Siagian, 2016). Komunikasi adalah suatu proses penyampaian informasi dari satu pihak kepada lain pihak untuk mendapatkan saling pengertian.

3. Masalah motivasi. Motivasi pegawai merupakan suatu kekuatan penggerak dalam prilaku individu dalam prilaku individu baik yang akan menentukan arah maupun daya tahan (perintence) tiap perilaku pegawai yang didalamnya terkandung pula unsur-unsur emosional insani yang berasangkutan. Motivasi, dapat menciptakan pelaksanaan tugas pekerjaan secara maksimal.

\section{LANDASAN TEORI}

1. Kinerja pegawai

Kinerja mempunyai arti penting bagi pegawai, oleh karena dengan adanya penilaian kinerja berarti pegawai mendapat perhatian dari atasannya, selain itu akan menambah gairah kerja pegawai, karena dengan penilaian kinerja ini pegawai-pegawai yang berprestasi dipromosikan, dikembangkan dan diberi penghargaan atas prestasi tersebut, sebaliknya pegawai yang tidak berprestasi akan didemosikan. Perlu diperhatikan, penilaian kerja yang efektif dan adil berkelanjutan akan meningkatkan motivasi dan prestasi kerja pegawai.

Menurut Mangkunegara (2015) kinerja adalah hasil kerja secara kualitas dan kuantitas yang dicapai oleh seorang pegawai dalam melaksanakan tugasnya sesuai dengan tanggung jawab yang diberikan kepadanya.

2. Kompensasi

Hasibuan (2015) mendefinisikan kompensasi sebagai semua pendapatan yang berbentuk uang, barang langsung atau tidak langsung yang diterima pegawai sebagai imbalan atas jasa yang diberikan kepada perusahaan. Kompensasi merupakan istilah luas yang berkaitan dengan imbalan-imbalan finansial (financial reward) yang diterima oleh orang-orang melalui hubungan kepegawaian mereka dengan sebuah organisasi. Pada umumnya, bentuk kompensasi adalah finansial karena pengeluaran moneter yang dilakukan oleh organisasi. Kompensasi bisa langsung, dimana uang langsung diberikan kepada pegawai, ataupun tidak langsung dimana pegawai menerima kompensasi dalam bentuk-bentuk non moneter.

3. Komunikasi 


\section{JESYA}

Jurnal Ekonomi \& Ekonomi Syariah Vol 4 No 2, Juni 2021

E-ISSN : 2599-3410 | P-ISSN : 2614-3259

DOI : https://doi.org/10.36778/jesya.v4i2.462

Perkembangan peran komunikasi saat ini bahwa komunikasi sebagai kunci untuk membuka potensi besar dari sumber daya manusia suatu organisasi. Menurut Handoko, (2011) komunikasi adalah proses pemindahan pengertian dalam bentuk gagasan atau informasi dari seseorang ke orang lain. Pemindahan pengertian tersebut melibatkan lebih dari sekedar katakata yang digunakan dalam percakapan, tetapi juga ekspresi wajah, inovasi, titik putus vokal. Komunikasi sangat penting perannya dalam kepemimpinan organisasi. Keberhasilan kepemimpinan itu tergantung pada kemampuan pimpinan dalam menjabarkan kebijakan (policy) organisasi dan ide-ide sendiri dalam pengertian-pengertian praktis, yang mudah dipahami dan dapat dilaksanakan oleh para bawahan.

4. Motivasi

Motivasi atau motivation berarti pemberian motif, penimbulan motif atau hal yang menimbulkan dorongan atau keadaan yang menimbulkan dorongan kerja (As'ad, 2015). Motivasi dapat pula diartikan faktor yang mendorong orang untuk bertindak dengan cara tertentu. Sedangkan motif adalah tenaga pendorong yang mendorong manusia untuk bertindak atau suatu tenaga di dalam diri manusia yang menyebabkan manusia bertindak.

\section{Kerangka Konseptual}

Berdasarkan teori dan hasil penelitian sebelumnya dan tujuan penelitian yang hendak dicapai, maka model penelitian ini dapat dikembangkan dalam kerangka pemikiran sebagai berikut:

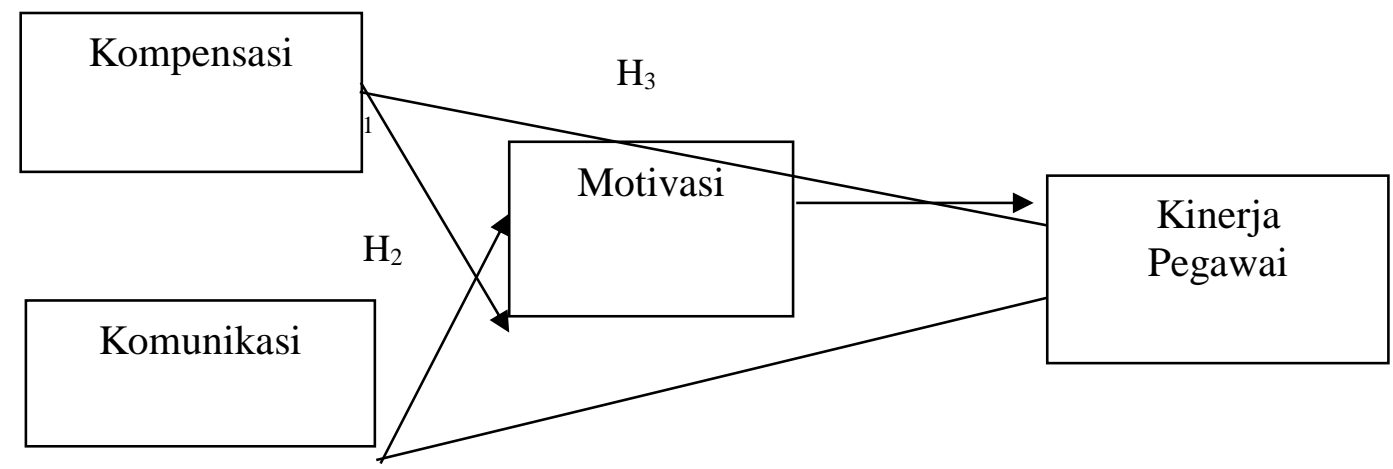

Gambar Kerangka Konseptual

\section{Hipotesis}

Hipotesis dalam penelitian ini adalah sebagai berikut:

H1.Kompensasi berpengaruh signifikan terhadap motivasi pegawai Kantor Ketahanan Pangan Kabupaten Klaten.

H2.Komunikasi berpengaruh signifikan terhadap motivasi pegawai Kantor Ketahanan Pangan Kabupaten Klaten.

H3.Kompensasi berpengaruh signifikan terhadap kinerja pegawai Kantor Ketahanan Pangan Kabupaten Klaten.

H4.Komunikasi berpengaruh signifikan terhadap kinerja pegawai Kantor Ketahanan Pangan Kabupaten Klaten.

H5.Motivasi berpengaruh signifikan terhadap kinerja pegawai Kantor Ketahanan Pangan Kabupaten Klaten. 


\section{METODE PENELITIAN}

Penelitian ini akan dilakukan pengujian yang akan menjelaskan pengaruh kompensasi dan komunikasi terhadap motivasi serta dampaknya pada kinerja pegawai Kantor Ketahanan Pangan Kabupaten Klaten. Metode pengumpulan data melalui survey dengan menggunakan bantuan kuesioner disebarkan langsung kepada responden yaitu para pegawai di Kantor Ketahanan Pangan Kabupaten Klaten.

\section{Lokasi dan Obyek Penelitian}

Penelitian dilakukan di Kantor Ketahanan Pangan Kabupaten Klaten. Sedangkan obyek penelitian adalah pegawai di Kantor Ketahanan Pangan Kabupaten Klaten.

\section{Populasi dan Sampel Penelitian}

\section{Populasi Penelitian}

Populasi penelitian ini adalah pegawai Kantor Ketahanan Pangan Kabupaten Klaten yang berjumlah 45 orang.

\section{Sampel dan Teknik sampling}

Sampel adalah contoh atau wakil dari suatu populasi yang cukup besar jumlahnya, yang dipertimbangkan dapat mewakili dan mencerminkan populasi yang ada. Jumlah sampel yang diambil berdasarkan metode sensus adalah 45 orang.

\section{Data dan Teknik Pengumpulan Data}

\section{Jenis dan Sumber data}

Ditinjau dari jenis data dan analisisnya, maka penelitian ini termasuk penelitian sampel dalam kategori data kuantitatif, dimana suatu pertanyaan memerlukan alternatif jawaban, sangat setuju, setuju, netral, kurang setuju, dan tidak setuju. Penilaian jawaban dengan menggunakan skala likert, di mana jawaban sangat setuju diberi nilai angka 5, setuju 4, netral 3, kurang setuju 2, dan tidak setuju 1. Dilihat dari sumbernya, data penelitian terbagi menjadi dua yaitu data primer dan data sekunder.

\section{Teknik Pengumpulan data}

1) Observasi yaitu pengamatan langsung di lapangan yang dilakukan untuk mendapat informasi atau data dari penelitian baik berupa subyek atau obyek yang bersangkutan.

2) Kuesioner adalah daftar pertanyaan yang berkaitan dengan tujuan penelitian. Metode ini dilakukan dengan cara memberikan kuesioner kepada responden.

Ditinjau dari jenis data dan analisisnya, maka penelitian ini termasuk penelitian total populasi dalam kategori data kuantitatif, dengan menggunakan skala dasar pengukuran Likert (Sugiyono, 2017) memakai urutan skala lima yaitu 1, 2, 3, 4 dan 5 yang mempunyai kriteria sebagai berikut :
a. Sangat setuju (SS)
$: 5$
b. Setuju (S)
$: 4$
c. Netral (N)
$: 3$
d. Tidak setuju (TS)
$: 2$
e. Sangat tidak setuju (STS) : 1 


\section{Teknik Analisis Data}

\section{Pengujian Instrumen}

\section{a. Uji Validitas}

Pengujian validitas dilakukan untuk mengetahui ketepatan pengukuran variabel atau instrumen yang digunakan dalam penelitian, yaitu mampu mengukur apa yang akan diukur dalam penelitian. Instrumen dikatakan valid bila item yang digunakan benar-benar mewakili konstruk yang akan diukur. Apabila instrumen dinyatakan valid berarti alat ukur yang digunakan dalam penelitian sudah tepat. Uji validitas dalam penelitian ini menggunakan teknik korelasi product moment. Suatu item dikatakan valid jika nilai probabilitas korelasi lebih kecil dari 0,05.

b. Uji Reliabilitas

Dalam hal ini, reliabilitas instrumen diukur dengan Cronbach's Alpha, yang mencerminkan konsistensi internal alat ukur. Dalam penelitian ini reliabilitas diukur dengan menggunakan teknik Cronbch's Alpha. Cronbach's Alpha harus lebih besar dari 0,60 (Nunnally dalam Ghozali, 2014).

\section{Uji Linieritas}

Uji linieritas merupakan langkah untuk mengetahui status linier tidaknya suatu distribusi sebuah data penelitian. Hasil yang diperoleh melalui uji linieritas akan menentukan teknik analisis regresi yang akan digunakan. Jika hasil uji linieritas merupakan data linier maka digunakan analisis regresi linier. Sebaliknya jika hasil uji linieritas merupakan data yang tidak linier maka analisis regresi yang digunakan non linier. Uji linier yang akan dilakukan adalah dengan uji Langrange Multiplivariat. Estimasi dengan uji ini bertujuan untuk mendapatkan nilai $\mathrm{C}^{2}$ hitung atau $\left(\mathrm{n} \times \mathrm{R}^{2}\right)$

\section{Uji Hipotesis}

\section{a. Analisis Jalur}

Teknik analisis statistic yang digunakan dalam penelitian ini adalah Path Analysis (Analisis Jalur). Dalam analisis jalur pengaruh independen variabel terhadap dependen variabel dapat berupa pengaruh langsung dan tidak langsung (direct dan indirect effect), atau dengan kata lain analisis jalur memperhitungkan adanya pengaruh langsung dan tidak langsung.

\section{1) Path Diagram (Diagram Jalur)}

Diagram jalur adalah alat untuk melukiskan secara grafis, struktur hubungan kausalitas antar variabel independen, intervening (intermediary) dan dependen.

2) Koefisien Jalur

Koefisien korelasi antar variabel independen dalam penelitian ini menggunakan koefisien korelasi Person yang diolah melalui SPSS, sedangkan untuk mengetahui kuat lemahnya hubungan antar variabel independen dan hubungan variabel independen dengan variabel dependen, maka dapat dinyatakan dengan fungsi linear (paling tidak mendekati) dan diukur dengan suatu nilai yang disebut koefisien korelasi. Penentuan kuat lemahnya koefisien korelasi (r) atau arti harga nilai $r$ akan dikonsultasikan dengan tabel interpretasi nilai r yang dikemukakan oleh oleh Sarwono, (2016).

Interpretasi koefisien korelasi nilai $\mathrm{r}$

\begin{tabular}{|c|c|}
\hline Koefisien korelasi & Penafsiran \\
\hline $0,80-1,00$ & Sangat kuat \\
\hline $0,60-0,799$ & Kuat \\
\hline $0,40-0,599$ & Cukup kuat \\
\hline
\end{tabular}




\begin{tabular}{|c|c|}
\hline $0,20-0,399$ & Rendah \\
\hline $0,00-0,200$ & Sangat rendah \\
\hline
\end{tabular}

3) Pengaruh Langsung dan Pengaruh Tidak Langsung

Pengaruh langsung adalah pengaruh dari satu variabel independen ke variabel dependen, tanpa melalui variabel dependen lainnya. Sedangkan pengaruh tidak langsung adalah situasi dimana variabel lain yang disebut variabel intervening (intermediary). Adapun yang dimaksud pengaruh total adalah penjumlahan pengaruh langsung dan pengaruh tidak langsung.

\section{b. Persamaan Struktur Regresi Jalur}

Hipotesis menyatakan bahwa variabel bebas mempunyai pengaruh yang signifikan terhadap variabel terikat. Pengujian kebenaran hipotesis ini digunakan pengujian koefisien regresi secara parsial atau uji-t dengan rumus sebagai berikut : (Irawan, dkk, 2011)

$$
\begin{aligned}
& \text { Persamaan 1: } Y_{1}=\beta_{0}+\beta_{1} X_{1}+\beta_{2} X_{2}+\varepsilon 1 \\
& \text { Persamaan 2: } Y_{2}=\beta_{0}+\beta_{1} X_{1}+\beta_{2} X_{2}+\beta_{3} X_{3}+\varepsilon \\
& \text { Keterangan : } \\
& \beta_{0} \quad=\text { Konstanta } \\
& \beta_{1} \beta_{2} \beta_{3}=\text { Koefisien variabel } X_{1} \ldots . . X_{3} \\
& \mathrm{Y}_{3}=\text { Kinerja pegawai } \\
& \mathrm{X}_{1} \quad=\text { Kompensasi } \\
& \mathrm{X}_{2} \quad=\text { Komunikasi } \\
& \mathrm{X}_{3} / \mathrm{Y} 1=\text { Motivasi } \\
& \mathrm{e} \quad=\text { Standard error }
\end{aligned}
$$

\section{c. Uji t}

Uji t ini digunakan untuk menguji pengaruh masing - masing variabel independen Apabila nilai signifikansi $<0,05$ maka Hipotesis diterima artinya hipotesis terbukti, apabila nilai signifikansi $>0,05$ maka Hipotesis ditolak artinya hipotesis tidak terbukti.

\section{d. Uji F .}

Uji ini dilakukan dengan program SPSS. Uji ini digunakan untuk menguji keberartian koefisien regresi secara bersama - sama / serentak Apabila nilai signifikansi < 0,05 maka Hipotesis diterima artinya hipotesis terbukti, apabila nilai signifikansi $>0,05$ maka Hipotesis ditolak artinya hipotesis tidak terbukti.

\section{e. $\quad \mathbf{j i} \mathbf{R}^{\mathbf{2}}$}

Koefisien determinansi merupakan suatu nilai yang menggambarkan total variasi dari y (variabel dependen) dari sebuah persamaan regresi. Nilai koefisen determinasi ini mencerminkan seberapa besar variasi dari variabel dependen dapat dijelaskan oleh variabel independen. Apabila nilai koefisien determinansi sama dengan 0 maka variasi dari variabel dependen tidak dapat dijelaskan oleh variabel independen. 
Sebaliknya apabila nilai Koefisien determinansi sama dengan 1 maka semua variasi variabel dependen dapat dijelaskan secara sempurna oleh variabel independen.

\section{f. Pengaruh Langsung dan Pengaruh Tidak Langsung dan Pengaruh Total}

Pengaruh langsung adalah pengaruh dari satu variabel independen ke variabel dependen, tanpa melalui variabel dependen lainnya. Sedangkan pengaruh tidak langsung adalah situasi dimana variabel lain yang disebut variabel intervening (intermediary). Adapun yang dimaksud pengaruh total adalah penjumlahan pengaruh langsung dan pengaruh tidak langsung..

\section{HASIL PENELITIAN}

\section{Hasil Uji Instrumen Penelitian}

a. Uji Validitas

Variabel Kompensasi, Komunikasi, Motivasi dan Kinerja, dengan pengujian validitas yang menggunakan teknik one shot methods yaitu dengan membandingkan nilai $\mathrm{r}_{\text {hitung }}$ dengan nilai $r_{\text {tabel }}$ didapatkan hasil uji untuk semua item pertanyaan dinyatakan semua valid karena mempunyai nilai $r_{\text {item }}$ lebih besar dari nilai $r_{\text {tabel. }}$.

b. .Uji Reliabilitas

Hasil uji reliabilitas

\begin{tabular}{|l|c|c|c|}
\hline \multicolumn{1}{|c|}{ Variabel } & Alpha Cronbach & Kriteria & Keterangan \\
\hline Kompensasi & 0,705 & Alpha Cronbach> & Reliabel \\
& & 0,60 maka reliabel & \\
Komunikasi & 0,688 & & Reliabel \\
Motivasi & 0,842 & & Reliabel \\
Kinerja & 0,829 & & Reliabel \\
\hline
\end{tabular}

Sumber: Data yang diolah, 2021

Dari hasil pengujian reliabilitas menunjukkan bahwa koefisien (r) alpha hitung seluruh variabel lebih besar dibandingkan dengan kriteria yang dipersyaratkan atau nilai kritis (rule of thumb) sebesar 0,6 sehingga dapat dikatakan bahwa butir-butir pertanyaan seluruh variabel dalam keadaan reliabel.

\section{Uji t untuk persamaan 1, 2:}

Hasil Uji t

\begin{tabular}{|c|c|c|c|c|}
\hline $\begin{array}{l}\text { Persa } \\
\text { maan }\end{array}$ & $\begin{array}{c}\text { Hubungan Antar } \\
\text { Variabel }\end{array}$ & Beta & Sig & Keterangan \\
\hline \multirow{2}{*}{1} & kompensasi $\rightarrow$ motivasi & 0,242 & 0,179 & Tidak Signifikan \\
\hline & komunikasi $\rightarrow$ motivasi & 0,434 & 0,018 & Signifikan \\
\hline \multirow{3}{*}{2} & kompensasi $\rightarrow$ kinerja & 0,411 & 0,001 & Signifikan \\
\hline & komunikasi $\rightarrow$ kinerja & 0,237 & 0,060 & Tidak Signifikan \\
\hline & motivasi $\rightarrow$ kinerja & 0,351 & 0,001 & Signifikan \\
\hline
\end{tabular}

Data diolah tahun 2021 
a. Dari hasil persamaan regresi persamaan 1 dapat dilihat nilai sig Kompensasi $(0,179)>$ 0,05 , berarti bahwa kompensasi berpengaruh tidak signifikan terhadap motivasi maka hipotesa yang menyatakan kompensasi berpengaruh signifikan terhadap motivasi, tidak terbukti.

b. Dari hasil persamaan regresi persamaan 1 dapat dilihat, nilai sig Komunikasi $(0,018)<$ 0,05 , berarti bahwa komunikasi berpengaruh signifikan terhadap motivasi maka hipotesa yang menyatakan kompensasi berpengaruh signifikan terhadap motivasi, terbukti.

c.. Dari hasil persamaan regresi persamaan 2 dapat dilihat nilai sig Kompensasi $(0,001)<$ 0,05 , berarti bahwa kompensasi berpengaruh signifikan terhadap kinerja maka hipotesa yang menyatakan kompensasi berpengaruh signifikan terhadap kinerja, terbukti.

d. Dari hasil persamaan regresi persamaan 2 dapat dilihat, nilai sig Komunikasi $(0,060)>$ 0,05, berarti bahwa komunikasi berpengaruh tidak signifikan terhadap kinerja maka hipotesa yang menyatakan kompensasi berpengaruh signifikan terhadap kinerja, tidak terbukti

e. Dari hasil persamaan regresi persamaan 2 dapat dilihat, nilai sig motivasi $(0,001)<$ 0,05 , berarti bahwa motivasi berpengaruh signifikan terhadap kinerja maka hipotesa yang menyatakan motivasi berpengaruh signifikan terhadap kinerja, terbukti.

\section{Uji F pada persamaan sebagai berikut:}

Hasil uji F menunjukkan bahwa kompensasi, dan komunikasi, motivasi mempunyai nilai $F_{\text {hitung }}$ sebesar 42,310 dengan nilai signifikansi sebesar $0,000<0,05$ sehingga secara simultan variabel kompensasi, komunikasi, motivasi berpengaruh positif dan signifikan terhadap kinerja

\section{Nilai Determinasi Total (R2)}

Berdasarkan nilai $e_{1}$ dan nilai $e_{2}$ maka nilai $R^{2}$ total adalah: 0,855 atau $85,5 \%$. Ini berarti bahwa kinerja pegawai dijelaskan oleh variabel kompensasi, komunikasi, motivasi sebesar 85,5\% dan sisanya sebesar 14,5\% dijelaskan variabel lain diluar model penelitian.

5. Pengaruh Langsung dan Pengaruh Tidak Langsung (Total Effect)

\begin{tabular}{|c|c|c|c|c|}
\hline NO & Arah Hubungan & $\begin{array}{l}\text { Pengaruh } \\
\text { Langsung }\end{array}$ & $\begin{array}{l}\text { Pengaruh Tak } \\
\text { Langsung }\end{array}$ & Total Pengaruh \\
\hline 1 & $\begin{array}{l}\text { Kompensasi } \rightarrow \text { Kinerja } \\
\text { pegawai } \\
\text { Kompensasi } \rightarrow \text { motivasi } \\
\text { pegawai } \rightarrow \text { Kinerja pegawai }\end{array}$ & 0,411 & $\begin{array}{l}=0,242 x \\
0,351=0,084\end{array}$ & $\begin{array}{l}=0,411 \\
0,084=0,495\end{array}$ \\
\hline 2 & $\begin{array}{l}\text { Komunikasi } \rightarrow \text { Kinerja } \\
\text { pegawai } \\
\text { Komunikasi } \rightarrow \text { motivasi } \\
\text { pegawai } \rightarrow \text { Kinerja pegawai }\end{array}$ & 0,237 & $\begin{array}{l}=0,434 \mathrm{x} \\
0,351=0,152\end{array}$ & $\begin{array}{lr}= & 0,237 \\
0,152= & 0,389\end{array}$ \\
\hline
\end{tabular}

Sumber: Data di olah, 2021

a. Berdasarkan hasil analisis menunjukkan bahwa pengaruh Langsung (direct effect) dari variabel kompensasi dan komunikasi lebih besar masing masing 0,411 dan 0,237 dari pengaruh tidak langsung (indirect effect) masing masing 0,084 dan 0,152 . Hal ini menunjukkan bahwa variabel intervening tidak effektif. 
b. Variabel kompensasi secara langsung efektif meningkatkan kinerja pegawai, karena mempunyai pengaruh yang paling besar $(0,411)$, positip dan signifikan.

\section{Diagram jalur}

Secara lengkap diagram jalur dalam gambar dibawah ini:

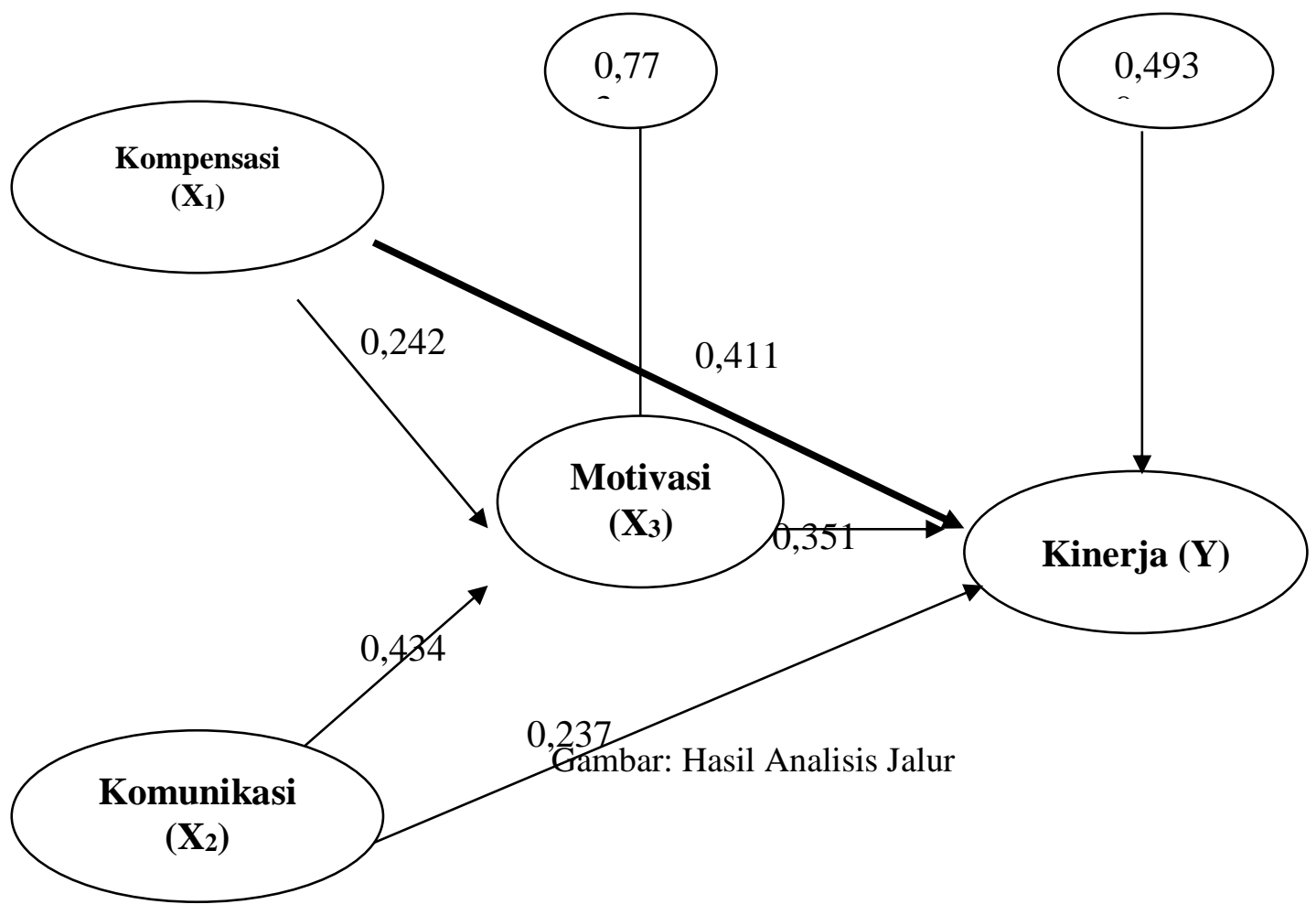

\section{Implikasi Manajerial}

\section{Pengaruh Kompensasi Terhadap Kinerja}

Hasil penelitian ini menunjukkan bahwa Kompensasi mempengaruhi secara langsung dan positip signifikan terhadap kinerja pegawai Kantor Ketahanan Pangan Kabupaten Klaten, hal ini mengindikasikan bahwa upaya semakin meningkatkan kompensasi maka menyebabkan Kinerja pegawai Kantor Ketahanan Pangan Kabupaten Klaten berdampak meningkat.

Berdasarkan hasil analisis menunjukkan bahwa pengaruh Langsung (direct effect) dari variabel kompensasi lebih besar dari pengaruh tidak langsung (indirect effect). Hal ini menunjukkan bahwa variabel intervening tidak effektif

Untuk itu, Kantor Ketahanan Pangan Kabupaten Klaten melakukan upaya peningkatan kompensasi yang lebih baik, dengan cara.
a. Meningkatkan gaji
b. Meningkatkan Insentif
c. Meningkatkan Ketepatan pembayaran kompensasi lebih baik
d. Meningkatkan Keadilan kompensasi 


\section{Pengaruh Komunikasi Terhadap Kinerja}

Hasil penelitian bahwa Komunikasi berpengaruh positip dan tidak signifikan secara langsung terhadap kinerja pegawai Kantor Ketahanan Pangan Kabupaten Klaten. Semakin baik komunikasi semakin tinggi kinerja pegawai.

Berdasarkan hasil analisis menunjukkan bahwa pengaruh Langsung (direct effect) dari variabel komunikasi lebih besar dari pengaruh tidak langsung (indirect effect). Hal ini menunjukkan bahwa variabel intervening tidak effektif

Berdasarkan penelitian ini pengaruh langsung terhadap kinerja positip dan tidak signifikan terhadap kinerja, maka langkah yang dilakukan Kantor Ketahanan Pangan Kabupaten Klaten adalah

a. Mempertahankan Tingkat/frekuensi berkomunikasi dengan para staf atau bawahan;

b. Mempertahankan pemberian arahan langsung kepada bawahan seperti selama ini;

c. Mempertahankan Jalinan komunikasi antara rekan sekerja;

d. Mempertahankan Rekan sekerja dapat saling memberikan masukan untuk perbaikan kinerja.

e. Mempertahankan Rekan sekerja membantu dalam menyelesaikan masalah pekerjaan.

f. Mempertahankan Komunikasi dengan bagian lain dalam satu dinas.

g. Mempertahankan Saling memberikan informasi yang dibutuhkan.

h. Mempertahankan Komunikasi sebagai pemecahan masalah

i. Mempertahankan Komunikasi sebagai konsultasi maupun diskusi

\section{Pengaruh Motivasi Terhadap Kinerja}

Hasil penelitian bahwa motivasi berpengaruh positip dan signifikan terhadap Kinerja pegawai pegawai Kantor Ketahanan Pangan Kabupaten Klaten. Hal ini mengindikasikan semakin tinggi motivasi pegawai semakin tinggi kinerja pegawai pegawai Kantor Ketahanan Pangan Kabupaten Klaten. Maka upaya-upaya peningkatan motivasi dengan langkah-langkah :

a. Meningkatkan kesejahteraan sebagai upaya pemenuhan kebutuhan sehari hari misalnya adanya insentif, bonus..

b. Meningkatkan kesejahteraan dalam bantuan perulahan pegawai.

c. Meningkatkan hubungan antar pegawai sehingga pegawai dapai bersosialisasi dengan harmonis.

d. Meningkatkan pemberian penghargaan yaitu yang berkaitan dengan prestasi, kemandirian, keberhasilan sehingga pegawai merasa senang dalam bekerja dan pemberian penghargaan yang berkaitan dengan reputasi pegawai, status atau kedudukan, pengakuan, yang membuat pegawai bangga atas yang dilakukan selama ini.

e. Meningkatkan kebutuhan akan kepuasan diri untuk mempergunakan potensi dan pengembangan diri.

\section{KESIMPULAN}

Hasil Uji t menunjukkan bahwa kompensasi berpengaruh tidak signifikan terhadap motivasi. Komunikasi berpengaruh signifikan terhadap motivasi. Kompensasi berpengaruh signifikan terhadap kinerja pegawai. Komunikasi berpengaruh tidak signifikan terhadap kinerja pegawai. Motivasi berpengaruh signifikan terhadap kinerja pegawai Hasil uji $\mathrm{F}$ menunjukkan bahwa secara simultan variabel kompensasi, komunikasi, motivasi berpengaruh positif dan signifikan terhadap kinerja pegawai. Hasil uji koefisien determinasi Total $85,5 \%$. Ini berarti bahwa 
kinerja pegawai dijelaskan oleh variabel kompensasi, komunikasi, motivasi sebesar 85,5\% dan sisanya sebesar $14,5 \%$ dijelaskan variabel lain diluar model penelitian misalnya lingkungan kerja. Berdasarkan hasil analisis menunjukkan bahwa variabel intervening tidak effektif. Variabel kompensasi secara langsung efektif meningkatkan kinerja pegawai, karena mempunyai pengaruh yang paling besar, positip dan signifikan

\section{DAFTAR PUSTAKA}

Armstrong, Michael. 2014. Seri Pedoman Manajemen : Manajemen Sumber Daya Manusia, Alihbahasa Sofyan Cikmat dan Haryanto. Penerbit Elex Media Komputindo. Jakarta

Arikunto, Suharsimi. 2011, Dasar-Dasar Evaluasi Pendidikan, Bumi Aksara. Jakarta.

As'ad. Mohamad.. 2015. Psikologi Industri. Edisi keempat. Yogyakarta. Liberty

Atmosoeprapto, K. 2015. Produktivitas Aktualisasi Budaya Perusahaan : Mewqjudkan Organisasi yang Efektif dan Efisien Melalui SDM Berdaya. Elex Media

Gibson, J.I, Ivancovich J. M., Donnelly, J.H. 2019, Organisasi Perilaku, Struktur, Proses. Alih Bahasa Nunuk Adiami, Edisi Kedelapan, Jilid H, Binarupa Aksara

Handoko, T. H.., 2011, Manajemen Personalia dan Sumber Daya Manusia. BPFE Yogyakarta.

Hasibuan, M. S.P., 2015, Manajemen Sumberdaya Manusia. Bumi Aksara, Jakarta.

Mangkunegara, A.A Anwar Prabu, 2017, Manajemen Sumber Daya Manusia Perusahaan, Cetakan Pertama, PT Remaja Rosdakarya, Bandung

Mangkuprawira, Syafri, 2014, Manajemen Sumber Daya Manusia Strategik, Ghalia Indonesia, Jakarta.

Martoyo, S. 2018,Manajemen Sumber Daya Manusia , BPFE,Yogjakarta

Nitisemito, Alex S., 2014, Manajemen Personalia (Manajemen Sumber Daya Manusia), Edisi ke13, Ghalia Indonesia, Jakarta.

Nurwati. (2013) Effect of Management Control to Organizational Culture, Compensation, Work Behavior and Employees Performance.(Studies in the Village Unit Cooperatives (KUD) in Southeast Sulawesi). Journal of Business and Management ISSN: 2278

Riduwan, 2015, Skala Pengukuran Variabel-Variabel Penelitian, Cetakan Kedelapan, Alfabeta, Bandung.

Robbin, Stephen P dan Coulter, Mary. 2019, Manajemen, Edisi Keenam, PT. Prenhallindo, Jakarta Siagian, Sondang P. 2008. Manajemen Sumber Daya Manusia. Bumi Aksara. Jakarta

Simamora, H., 2015, Manajemen Sumber Daya Manusia. STIE YKPN Yogyakarta

Sugiyono, 2014, Metode Penelitian Administrasi. Alfabeta. Jakarta.

Suradinata, 2019, Penilaian Prestasi Kerja. Cetakan Ketiga. Penerbit PT. Pustaka Binawan Pressindo. Jakarta 